\title{
Aplikasi Pengelolaan Data Kepegawaian Berbasis Web Pada PT. Pelayaran Sakti Inti Makmur Palembang
}

\author{
Novan Wijaya ${ }^{[]^{*}}$, Adelia Rizky Febriyanti ${ }^{[2]}$, Anton Wibowo ${ }^{[3]}$ \\ Program Studi Manajemen Informatika AMIK MDP ${ }^{[1,2,3]}$ \\ Jalan Rajawali No.14 Palembang, Sumatera Selatan, Indonesia, 30113 \\ novan.wijaya@mdp.ac.id ${ }^{[1]}$, adelia_rizfe@mhs.mdp.ac.id ${ }^{[2]}$, antonaja@mhs.mdp.ac.id ${ }^{[3]}$
}

\begin{abstract}
PT. Pelayaran Sakti Inti Makmur is a express bahari fast boat operator company that has served people of Indonesia since 1990 until today in iall Indonesia waters. PT. Pelayaran Sakti Inti Makmur still uses a manual system such as recap data everyday, week and month. Manually, system often have errors in the recap process, both have the same data and even missing data. The application to be built aims to make it easier to manage staffing data at PT. Pelayaran Sakti Inti Makmur so that it becomes more effective and efficient. Staffing data includes calculating employee work period automatically, assisting in taking care of permits, leave, resignation, warning letters, and simplifying HRD in the process of making reports. Data collection techniques used were interviews, observation and literature study. System development methodology used is iterative method, which in iterative method includes the stages of analysis, design, program code creation and testing to describe proposed application using rich picture, DFD, Context Diagram, and ERD. This application is created using the PHP programming language and database management using MySQL.
\end{abstract}

Keywords: Application, iterative Method, PHP, DFD

Abstrak-- PT. Pelayaran Sakti Inti Makmur adalah perusahaan operator kapal cepat Express Bahari yang telah melayani masyarakat Indonesia sejak tahun 1990 sampai dengan saat ini diseluruh perairan Indonesia. Pada PT. Pelayaran Sakti Inti Makmur masih menggunakan sistem secara manual seperti melakukan rekap data setiap hari, minggu dan bulanan. Sistem secara manual seringkali terjadi kesalahan dalam proses rekap baik terdapat 2 data yang sama bahkan terdapat data yang hilang. Aplikasi yang akan dibangun bertujuan untuk mempermudah dalam mengatur data kepegawaian pada PT. Pelayaran Sakti Inti Makmur sehingga menjadi lebih efektif dan efisien. Data kepegawaian meliputi menghitung masa kerja pegawai secara otomatis, membantu dalam mengurus surat izin, cuti, pengunduran diri, surat peringatan (SP) menjadi lebih mudah, dan mempermudah HRD dalam proses pembuatan laporan. Teknik pengumpulan data yang digunakan ialah wawancara, observasi dan studi pustaka. Metodologi pengembangan sistem yang digunakan adalah metode iterative, dimana dalam metode iterative meliputi tahap analisis, desain, pembuatan kode program dan pengujian dan untuk menggambarkan aplikasi yang diusulkan menggunakan rich picture, DFD, Diagram Konteks dan ERD. Aplikasi ini dibuat menggunakan bahasa pemograman PHP dan database manajemen menggunakan MySQL.

Kata Kunci: Aplikasi, Metode Iteratif, PHP, DFD

\section{PENDAHULUAN}

Pengolahan data kepegawaian merupakan sebuah sistem yang digunakan untuk proses penyimpanan dan pengolahan data yang berkaitan dengan pegawai untuk mendukung operasional kepegawaian. Pemanfaatan sistem operasional kepegawaian dapat membantu suatu perusahaan untuk memudahkan pengguna dalam melakukan pengolahaan data sehingga dapat berjalan dengan cepat dan lancar. PT. Pelayaran Sakti Inti Makmur adalah perusahaan operator kapal cepat Express Bahari yang telah melayani masyarakat Indonesia sejak tahun 1990 sampai saat ini diseluruh perairan Indonesia. PT. Pelayaran Sakti Inti Makmur, terkhusus HRD, masih menerapkan sistem manual dalam melakukan pengolahan dara kepegawaian, diantaranya proses rekapitulasi data pegawai, cuti pegawai, absensi, surat peringatan, dan sebagainya. Sistem pengolahan data yang dilakukan secara manual dapat mengakibatkan lambatnya proses operasional pada bagian HRD. Sementara HRD harus menangani data pegawai yang jumlahnya cukup banyak. Data kepagawaian yang dimaksud meliputi data pegawai (masa kerja/masa pension), cuti pegawai, surat izin, absensi dan surat peringatan.

Penelitian yang terkait dengan Aplikasi Pengolahan Data Kepegawaian diantaranya berjudul "Sistem Informasi Administrasi Data Kepegawaian" menyatakan bahwa sistem informasi administrasi data kepegawaian pada bagian personalia masih dilakukan secara manual sehingga pemakaian data secara bersamaan pada masing-masing unit tidak dapat dilakukan yang mengakibatkan lambatnya proses yang berjalan di bagian personalia Padahal bagian personalia menangani data pegawai yang jumlahnya cukup banyak. Data kepegawaian disini meliputi data pegawai, absensi, mutasi karyawan, laporan kesehatan, training dan surat peringatan[1].

Selanjutnya penelitian yang berjudul "Perancangan Sistem Informasi Kepegawaian" hasil penelitian menunjukan bahwa pencatatan administrasi masih manual menggunakan buku bahkan kadang tidak dicatat sama sekali sehingga data-data mengenai kepegawaian kadang hilang atau berserakan, hal ini juga menyebabkan pada saat pengajuan kenaikan kepangkatan maupun penggajuan kepensiunan yang membutuhkan arsip dari bagian administrasi yang tidak tertata rapi menyebabkan 
pengajuan pensiun menjadi lebih lama karena tidak terorganisasinya penyimpanan arsip tersebut[2].

Dengan permasalahan yang ada pada PT. Pelayaran Sakti Inti Makmur dirancanglah sebuah aplikasi web based dalam proses pengolahan dara kepagawaian yang dilakukan HRD. Aplikasi yang dirancang diharapkan mampu menyelesaikan permasalahan-permasalahan yang sering terjadi pada PT. Pelayaran Sakti Inti Makmur.

\section{TINJAUAN PUSTAKA}

\section{A. Kepegawaian}

Kepegawaian merupakan sebuah kegiatan mengelola sumber daya manusia pada sebuah organisasi. Pada dasarnya kepegawaian adalah sebuah kegiatan mengelola kepangkatan, kewajiban, pembinaan pegawai serta hak yang harus didapat oleh pegawai tersebut[2].

\section{B. Aplikasi}

Aplikasi adalah program yang ditulis dan diterjemahkan oleh perangkat lunak bahasa untuk menyelesaikan suatu aplikasi tertentu[3].

\section{Metodologi Iterasi}

Metode iterasi (Iterative) adalah mengkombinasikan proses-proses pada model air terjun dan iterative pada model prototype. Model incremental akan menghasilkan versi-versi perangkat lunak yang sudah mengalami penambahan fungsi untuk setiap pertambahannya. Metode Inkremental dibuat untuk mengatasi kelemahan dari model air terjun yang tidak mengakomodasi iterasi, dan mengatasi kelemahan dari metode prototype yang memiliki proses terlalu pendek dan setiap prosesnya tidak selalu menghasilkan produk[4]. Adapun tahapan-tahapan dalam metodologi iterative ini yaitu:

\section{Tahapan Analisis Kebutuhan Perangkat Lunak}

Pada tahapan ini proses pengumpulan data dilakukan secara intensif untuk menspesifikasikan kebutuhan perangkat lunak agar dapat dipahami perangkat unak seperti apa yag dibutuhkan user. Spesifikasi pada tahapan ini perlu untuk di dokumentasikan.

\section{Tahapan Desain}

Desain perangkat lunak adalah proses multi langkah yang fokus pada desain pembuatan program perangkat lunak termasuk struktur data, arsiketur perangkat lunak, representasi antarmuka, dan prosedur pengodean. Tahap ini mentranslasi kebutuhan perangkat lunak dari tahapan analisis kebutuhan representasi desain agar dapat diimplementasikan menjadi program tahap selanjutnya. Desain perangkat lunak yang dihasilkan pada tahap ini juga perlu didokumentasikan.

\section{Tahapan Pengkodean}

Desain harus ditranslasikan ke dalam program perangkat lunak. Hasil dari tahap ini adalah program computer sesuai dengan desain yang telah dibuat pada tahap.

\section{Tahapan Pengujian}

Pada tahapan ini merupakan suatu cara untuk melakukan uji program yang telah dibuat, pengujian difokuskan pada perangkat lunak dari segi fungsional dan memastikan bahwa semua bagian sudah diuji. Hal ini dilakukan untuk meminimalisir kesalahan (error) dan memastikan keluaran yang dihasilkan sesuai yang diinginkan.

\section{Metode Pengumpulan Data}

Metode pengumpulan data merupakan tahapan awal untuk menganalisis suatu sistem yang memerlukan data. Metode pengumpulan data pada penelitian ini terdiri dari beberapa metode wawancara, observasi, dan studi pustaka[5].

Wawancara merupakan pengumpulan data menggunakan teknik wawancara lebih mudah dalam menggali bagian sistem nama yang dianggap baik dan bagian mana yang dianggap kurang baik[6].

Observasi mempunyai keuntungan yaitu analisis dapat melihat langsung bagaimana sistem lama berjalan, mampu menghasilkan gambaran lebih baik jika dibanding dengan teknik lainnya[6].

Studi pustaka atau kepustakaan dapat diartikan sebagai serangkaian kegiatan yang berkenaan dengan metode pengumpulan data pustaka, membaca dan mencatat serta mengolah bahan penelitian[6].

\section{E. My Structured Query Language (MySQL)}

MySQL merupakan sistem database yang banyak digunakan untuk pengembangan aplikasi web. Alasanya mungkin karena gratis, pengolahan datanya sederhana, memiliki tingkat keamanan yang bagus, mudah diperoleh, dan lain-lain[7].

\section{F. Hypertext Preprocessor (PHP)}

PHP adalah bahasa pemrograman scripting yang pertama dikembangan untuk menghasilkan statement HTML. Bahkan program yang dikembang dengan PHP seratus persen, tetap ditampilkan dalam bentuk kode HTML[8].

\section{G. Database}

Database atau biasa disebut basis data merupakan kumpulan data yang saling berhubungan. Data tersebut biasanya terdapat dalam tabel-tabel yang paling berhubungan satu sama lain, dengan mengunakan field/kolom pada setiap tabel yang ada[9].

\section{H. Data Flow Diagram (DFD)}

Data Flow Diagram (DFD) merupakan diagram yang digunakan untuk menggambarkan proses-proses yang terjadi pada sistem yang akan dikembangkan[10] 


\section{Entity Relationship Diagram (ERD)}

Entity Relationship Diagram digunakan untuk pemodelan basis data relasional gambar atau diagram yang menunjukkan informasi dibuat, disimpan, dan digunakan dalam sistem bisnis. Entitas biasanya menggambarkan jenis informasi yang sama. Dalam entitas digunakan untuk menghubungkan antar entitas yang sekaligus menunjukkan hubungan antar data. ERD bisa juga digunakan untuk menunjukkan aturan - aturan bisnis yang ada pada sistem informasi yang akan dibangun[4]

\section{METODOLOGI PENELITIAN}

\section{A. Prosedur Yang Berjalan}

1. Prosedur Data Pegawai

Gambar 1 menggambarkan prosedur yang berjalan saat pegawai PT. Pelayaran Sakti Inti Makmur harus mengambil formulir data pegawai baru pada bagian HRD dan mengisi formulir tersebut dan menyerahkan formulir itu kembali pada bagian HRD lalu HRD menyerahkan formulir tersebut kepada pimpinan. Data yang telah disetujui oleh pimpinan, akan diarsipkan kedalam ordner yang telah ada sebelumnya.

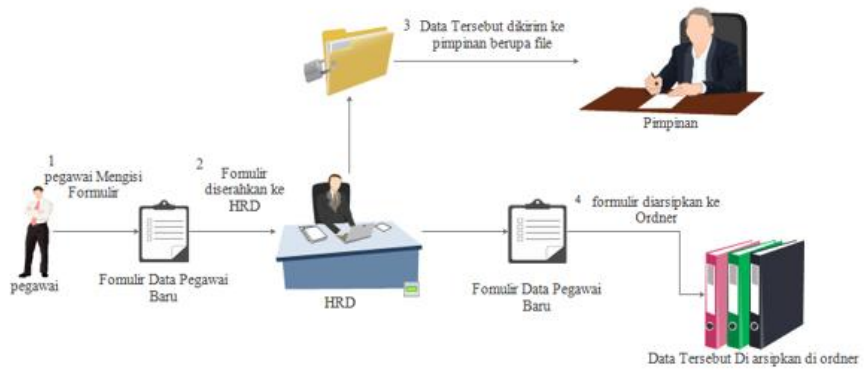

Gambar 1. Prosedur data pegawai yang sedang berjalan

2. Prosedur Cuti Pegawai

Gambar 2 menjelaskan mengenai prosedur pengajuan cuti pegawai saat ini, pegawai PT. Pelayaran Sakti Inti Makmur harus mengambil formulir cuti pegawai pada bagian HRD dan mengisi formulir tersebut dan menyerahkan formulir itu kembali pada bagian HRD lalu HRD menyerahkan formulir tersebut kepada pimpinan untuk mendapatkan persetujuan cuti.

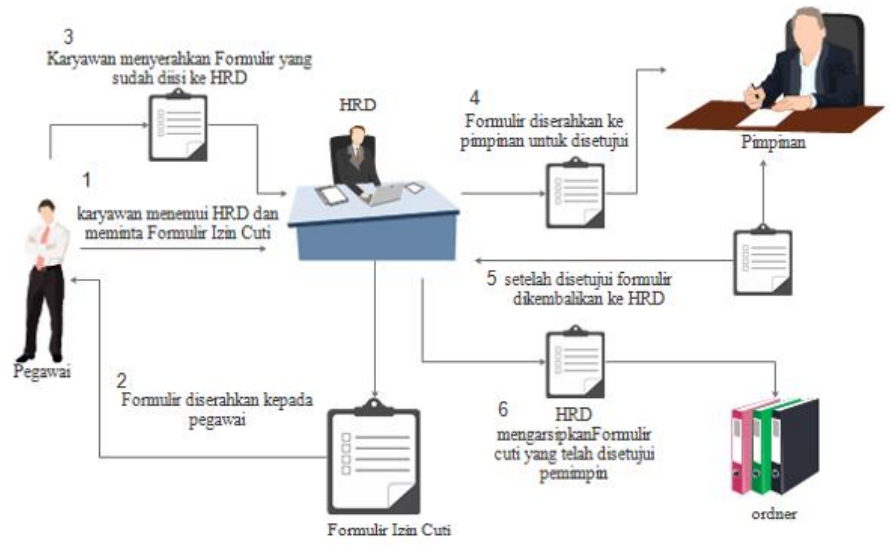

Gambar 2. Prosedur cuti pegawai yang sedang berjalan
3. Prosedur Absensi

Pegawai melakukan absensi dengan cara mengisi tanda tangan di kertas absensi sebagai bukti kehadiran pegawai tersebut, lalu kertas absensi direkap dalam Microsoft Excel selama seminggu sekali (Gambar 3).

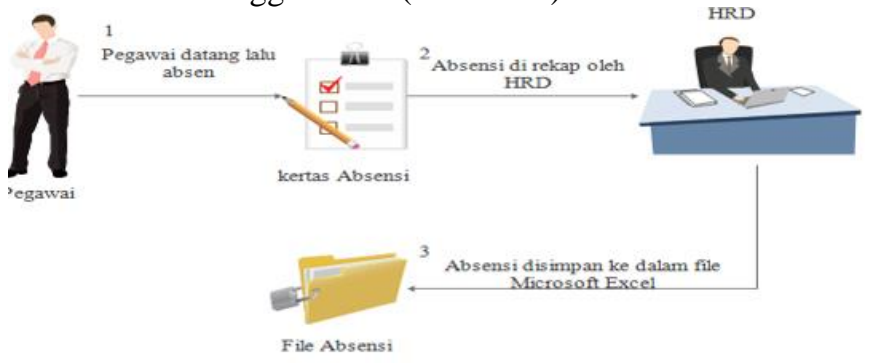

Gambar 3. Prosedur absensi yang sedang berjalan

\section{Prosedur Surat Peringatan}

Prosedur berjalan dalam menerbitkan surat peringatan PT. Pelayaran Sakti Inti Makmur bisa dilihat pada gambar 4. Surat peringatan dibuat oleh HRD dan diberikan ke pegawai yang melakukan pelanggaran seperti seringnya pegawai tidak masuk kerja ke kantor dan melakukan pelanggaran pada aturan kantor lainya.

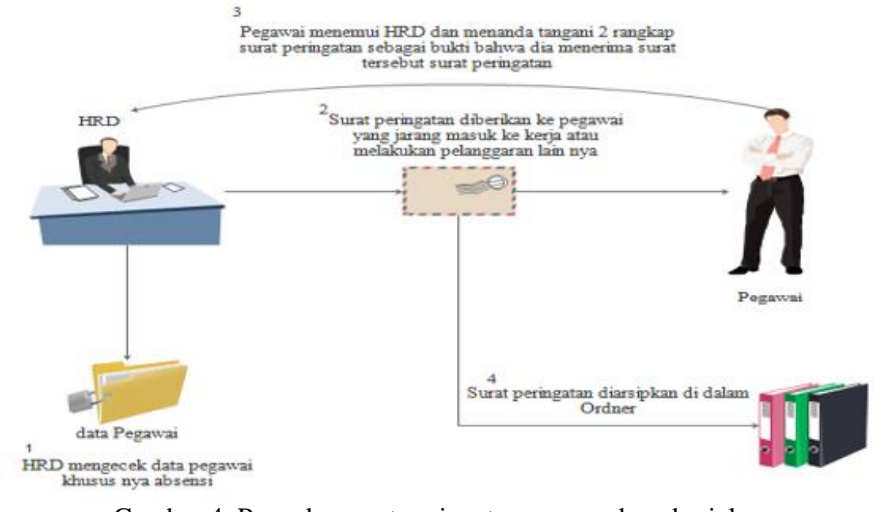

Gambar 4. Prosedur surat peringatan yang sedang berjalan

5. Prosedur Pengunduran Diri

Gambar 5 menggambarkan prosedur pengunduran diri yang diajukan oleh pegawai, dimana pegawai datang menghadap HRD dengan membawa surat pengunduran diri lalu menyerahkan ke HRD jika hrd menyertujui pengajuan itu maka surat akan diserahkan ke pimpinan untuk disetujui lalu diarsipkan.

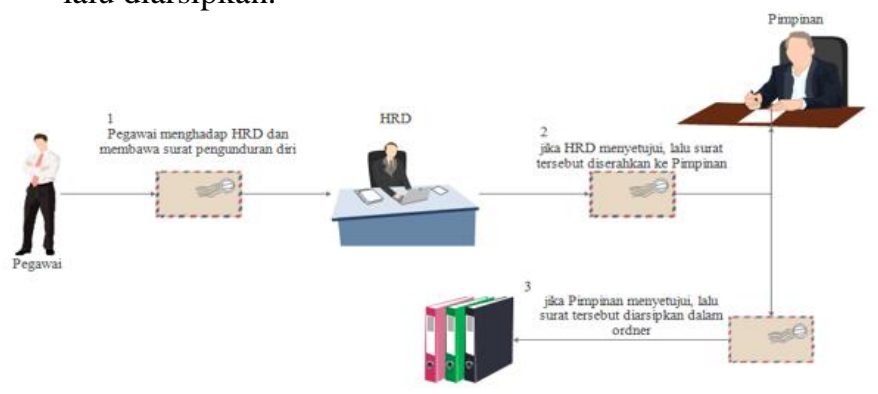

Gambar 5. Prosedur pengunduran diri yang sedang berjalan 
6. Prosedur Pensiun

Gambar 6 menjelaskan prosedur berjalan pada PT. Pelayaran Sakti Inti Makmur dalam pengajuan pensiun pegawai. Pegawai dengan mengahadap surat pengajuan pensiun lalu menyerahkan ke HRD lalu HRD mengecek data pegawai tersebut untuk memastikan umur pegawai tersebut jika HRD menyertujui pengajuan itu maka surat akan diserahkan ke pimpinan untuk disetujui lalu diarsipkan.

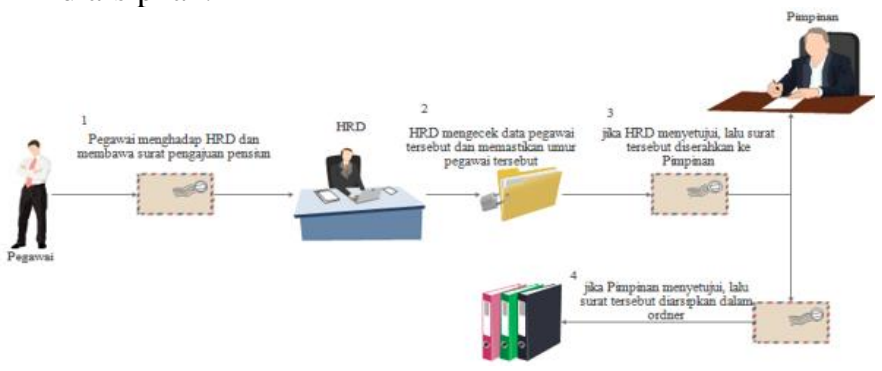

Gambar 6. Prosedur pensiun yang sedang berjalan

\section{B. Hasil Analisis}

Metode yang digunakan dalam menganilisis permasalahan yang terjadi di PT. Pelayaran Sakti Inti Makmur menggunakan metode sebab akibat. Diagram sebab-akibat (Cause and Effect diagram) merupakan salah satu metode untuk menganalisa penyebab dari sebuah masalah atau kondisi[11]. Pada PT. Pelayaran Sakti Inti Makmur akan dianalisa terlebih dahulu permasalahan-permsalahan yang terjadi. Setelah permasalahan didapatkan, akan dicarikan penyebab munculnya permasalahan tersebut serta akibat yang ditimbulkan dari masalah tersebut. Kemudian akan diberikan rekomendasi dengan aplikasi sebagai solusi untuk mengurangi permasalahan

\section{Tabel 1. Hasil Analisis I}

\begin{tabular}{|l|l|}
\hline Permasalahan & $\begin{array}{l}\text { Tidak adanya pemberitahuan ataupun informasi } \\
\text { pada pegawai yang memasuki masa pensiun dan } \\
\text { habis kontrak }\end{array}$ \\
\hline Sebab & $\begin{array}{l}\text { HRD harus mengecek data pegawai dan mencari } \\
\text { nama pegawai untuk melihat masa kontrak, lalu } \\
\text { HRD juga harus menghitung secara manual umur } \\
\text { pegawai untuk mengetahui pegawai yang akan } \\
\text { sudah memasuki masa pensiun. }\end{array}$ \\
\hline Akibat & $\begin{array}{l}\text { Pemberitahuan masa kontrak kerja tidak ada dan } \\
\text { HRD harus mengecek file dan membuat surat } \\
\text { pemberitahuan bahwa pegawai tersebut sudah } \\
\text { memasuki masa pensiun atau kontrak kerja sudah } \\
\text { habis. }\end{array}$ \\
\hline Rekomendasi & $\begin{array}{l}\text { Membuat aplikasi pengolahan data kepegawaian } \\
\text { dalam bentuk komputerisasi yang bertujuan untuk } \\
\text { membantu HRD dalam mendapatkan pemberitahuan } \\
\text { secara otomatis masa kerja kerja pegawai dan } \\
\text { pegawai yang memasuki masa pensiun. }\end{array}$ \\
\hline
\end{tabular}

Tabel 2. Hasil Analisis II

\begin{tabular}{|l|l|}
\hline Permasalahan & $\begin{array}{l}\text { Pengarsipan fomulir cuti, izin } \\
\text { kerja dan surat peringatan tidak } \\
\text { terdokumentasi dengan baik. }\end{array}$ \\
\hline
\end{tabular}

\begin{tabular}{|l|l|}
\hline Sebab & $\begin{array}{l}\text { Semua formulir cuti, izin kerja } \\
\text { dan surat peringatan diarsipkan } \\
\text { dan di letakan di ordner }\end{array}$ \\
\hline Akibat & Saat HRD ingin merekap semua \\
data tersebut ia harus merekap \\
dengan cara membuka dokumen \\
satu persatu dikarenakan \\
dokumen diarsipkan diordner \\
yang berbeda \\
\hline Rekomendasi & aplikasi pengolahan data \\
& kepegawaian menyediakan form \\
& untuk cuti kerja, izin kerja dan \\
& surat surat peringatan yang \\
& setelah diisi oleh pegawai dan \\
& akan langsung bisa dikirim \\
& melalui web yang akan diterima \\
& langsung oleh HRD untuk \\
& disetujui dan data-data tersebut \\
& bisa langsung disimpan ke dalam \\
database untuk pengarsipan.
\end{tabular}

Tabel 3. Hasil Analisis III

\begin{tabular}{|l|l|}
\hline Permasalahan & $\begin{array}{l}\text { Proses rekap laporan masih memakan waktu lama } \\
\text { dikarenakan staff HRD harus menggabungkan file } \\
\text { yang terpisah seperti data pegawai, cuti pegawai, } \\
\text { absensi dan surat peringatan, kemudian baru } \\
\text { diserahkan kepada Pimpinan. }\end{array}$ \\
\hline Sebab & $\begin{array}{l}\text { Data laporan yang meliputi data pegawai, cuti } \\
\text { pegawai, absensi dan surat peringatan akan di rekap } \\
\text { menjadi 1 menjadi laporan yang akan di serahkan ke } \\
\text { pimpinan }\end{array}$ \\
\hline Akibat & $\begin{array}{l}\text { data pegawai, cuti pegawai, absensi dan surat } \\
\text { peringatan tersimpan diberbagai file berbeda dan } \\
\text { digabungkan menjadi 1 sebagai laporan hal ini cukup } \\
\text { memakan waktu yang lama. }\end{array}$ \\
\hline Rekomendasi & $\begin{array}{l}\text { Membuat aplikasi pengolahan data kepegawaian } \\
\text { dapat membuat laporan menjadi lebih cepat sehingga } \\
\text { dapat membuat waktu menjadi lebih singkat ketika } \\
\text { pimpinan meminta laporan kepada HRD. }\end{array}$ \\
\hline
\end{tabular}

\section{Diagram Konteks}

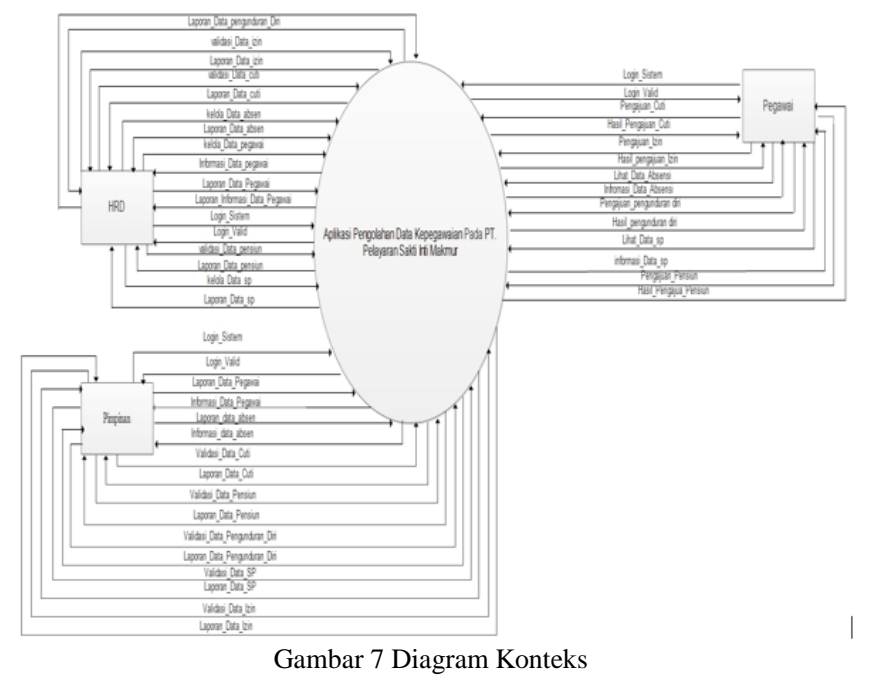

Diagram konteks pada sistem ini entitas yang digunakan yaitu Pimpinan, HRD, Pegawai (Gambar 7). Pegawai akan 
melakukan login pada aplikasi agar bisa mengajukan cuti,izin, pengunduran diri. Aplikasi akan mengkonfirmasi masih dengan melihatkan hasil dari cuti, izin serta pengunduran diri. Pegawai juga bisa melihat SP (Surat Peringatan) yang pernah diterima selama bekerja pada perusahaan. Pegawai mempunyai username yang berbeda-beda sehingga pegawai hanya bisa melihat informasi yang ada pada login username tersebut.

Entitas HRD bisa melakukan olah data pegawai di aplikasi pengolahan data kepegawaian PT. Pelayaran Sakti Inti Makmur. HRD akan memvalidasikan pengajuan dari pegawai baik itu cuti, izin serta pengunduran diri. Kemudian HRD bisa melakukan kelola data pegawai baik pegawai baru atau pegawai yang akan memasuki masa pensiun.

Pimpinan memiliki akses di aplikasi dengan melihat laporan-laporan yang sebelumnya telah di kelola oleh HRD. Bilamana pengajuan yang diajukan oleh HRD memerlukan konfirmasi dari pimpinan seperti cuti, izin, pengunduran diri serta pension makan pimpinan akan mengkonfirmasi pada aplikasi tersebut dan kemudian akan diteruskan kepada HRD dan pegawai yang bersangkutan. Entitas ini saling berhubungan diagram konteks sistem yang diusulkan dapat dilihat pada gambar 7 .

\section{Diagram Nol}

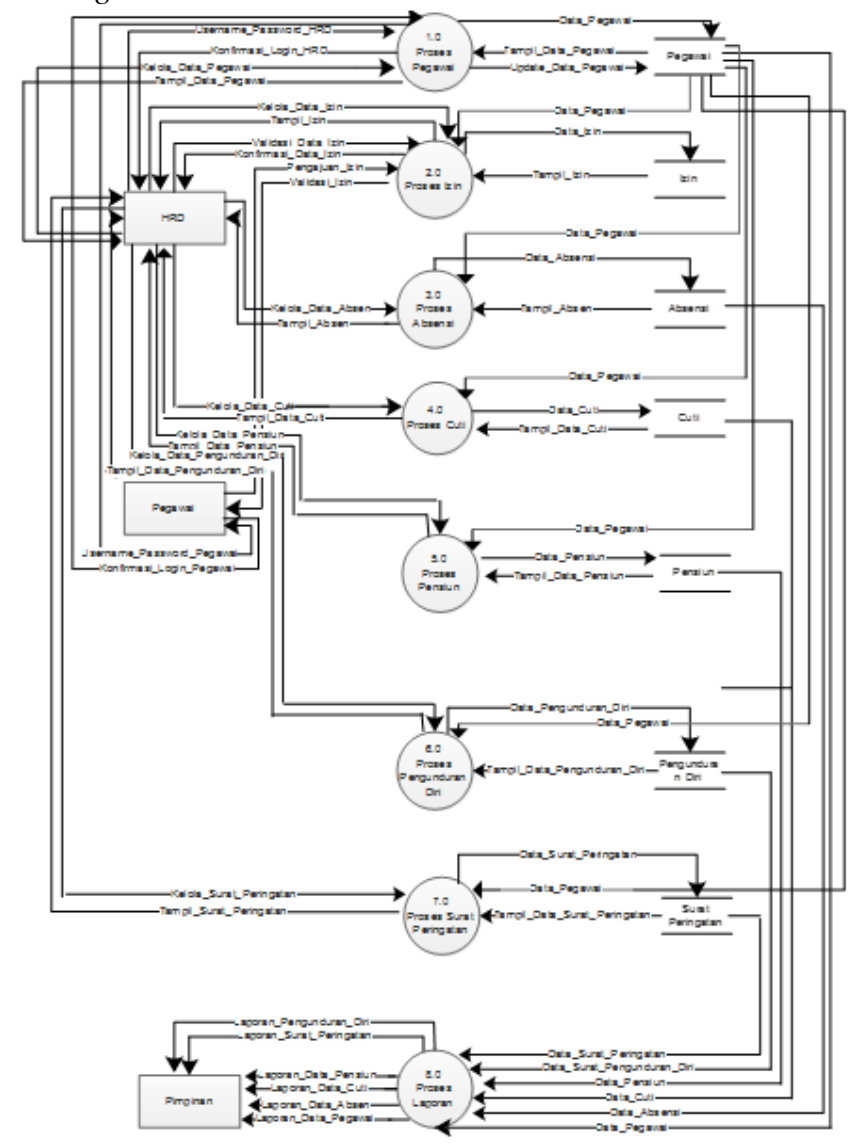

Gambar 8. Diagram Nol

Pada diagram Nol menjelaskan proses-proses yang terjadi pada aplikasi yang telah dikembangkan. Secara garis besar, proses yang terjadi sama dengan diagram konteks tetapi pada diagram nol lebih rinci. Entitas pegawai akan melakukan proses pengajuan cuti, izin, serta pengunduran diri pada aplikasi yang kemudian pengajuan tersebut akan di validasi oleh HRD. Pengajuan yang telah dilakukan akan tersimpan pada data store izin, cuti serta pengunduran diri. Pimpinan juga mendapatkan laporan dari data store setelah pengajuan yang telah dilakukan HRD.

\section{E. Diagram Rinci}

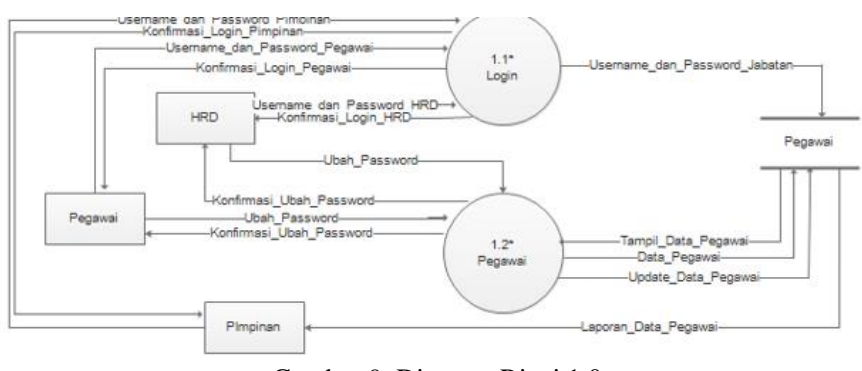

Gambar 9. Diagram Rinci 1.0

Gambar 9 menjelaskan proses autentikasi dari pegawai, hrd, dan pimpinan. Login akan didapatkan ketika para user akan melakukan login pertama kali. Setiap entitas mempunyai username yang berbeda-beda berdasarkan NIK yang didapatkan dari perusahaan.

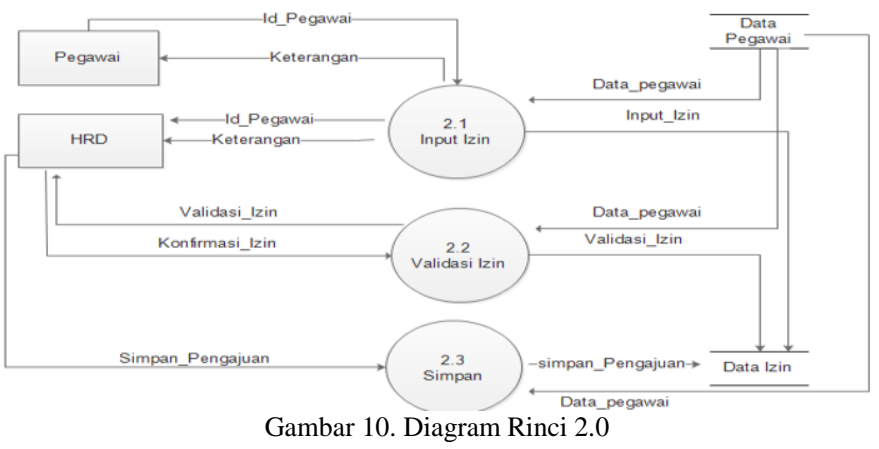

Gambar 10 menjelaskan pegawai melakukan proses pengajuan izin dimana ketika proses pengajuan tersebut selesai, hrd akan melakukan validasi dan konfirmasi dari pengajuan izin tesebut.

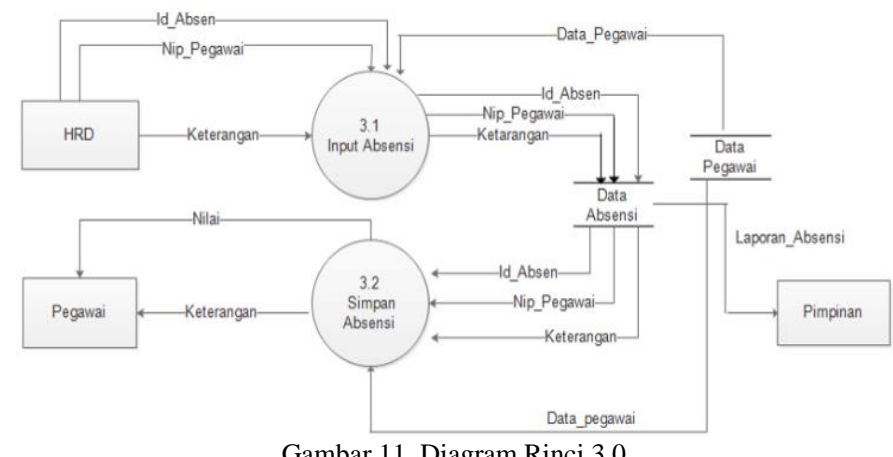

Gambar 11. Diagram Rinci 3.0 
Gambar 11 menjelaskan proses yang terjadi ketika pegawai akan melihat absensi. Pegawai hanya bisa melihat rekapitulasi dari absensi kerja. HRD akan melakukan laporan data pegawai berdasarkan absensi dan akan diteruskan kepada pimpinan.

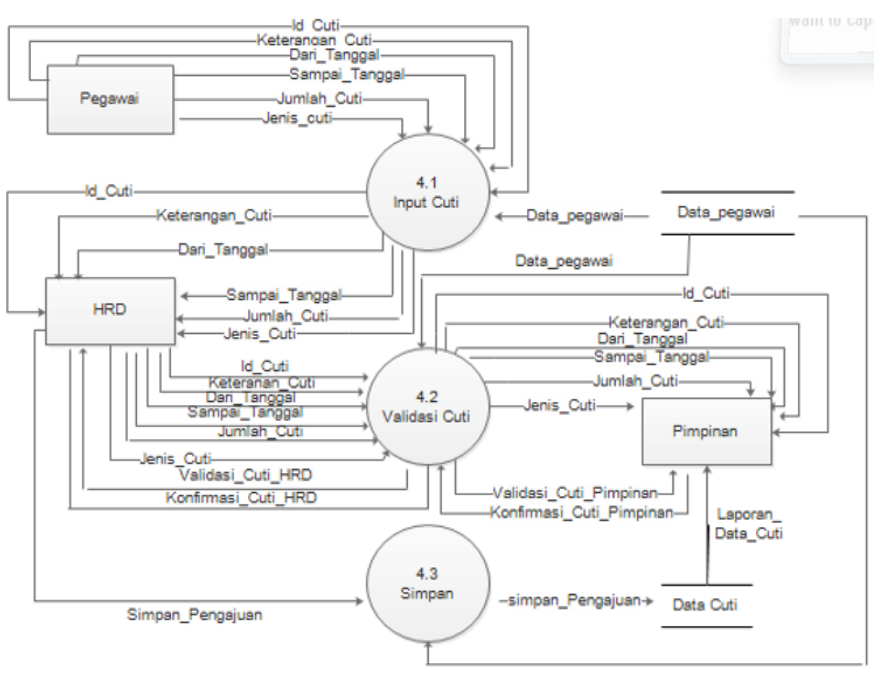

Gambar 12. Diagram Rinci 4.0

Proses pengajuan cuti yang dilakukan oleh pegawai akan di validasi dan akan di konfirmasi oleh hrd yang dimana sebelumnya akan di validasi oleh pimpinan. Pimpinan dan hrd akan melakukan kroscek baik alasan dari pengajuan cuti dan berapa lama cuti yang akan dilakukan.

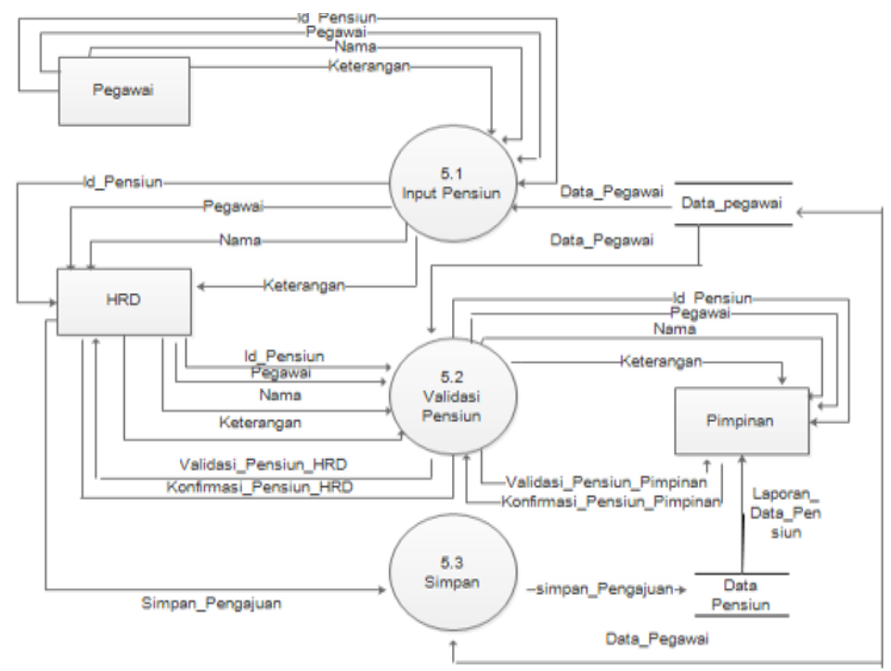

Gambar 13. Diagram Rinci 5.0

HRD akan melakukan proses rekapitulasi dari data-data pegawai yang akan memasuki masa pension, sehingga pegawai tersebut akan mendapatkan notifikasi pada aplikasi. Pegawai yang telah memasuki masa pension, akan melakukan pengajuan cuti di sistem dan akan di validasi dan konfirmasi oleh hrd melalui sistem.

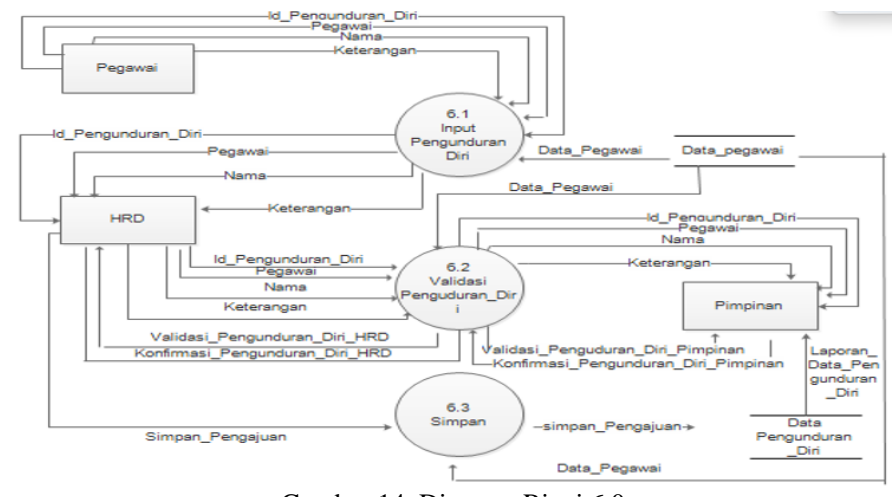

Gambar 14. Diagram Rinci 6.0

Gambar 14 menjelaskan proses pegawai yang akan melakukan proses pengunduran diri. Pegawai akan mengisi data-data terkait proses pengunduran diri serta alasan dari pengajuan tersebut. Pengajuan akan dilakukan proses validasi dan akan di konfirmasi baik melalui pimpinan maupun dari hrd dan akan dikembalikan kepada pegawai mengenai pengunduran diri tersebut.

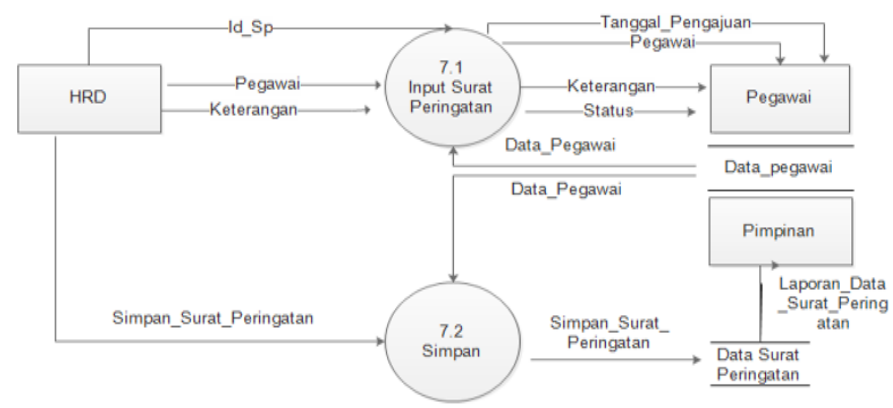

Gambar 15. Diagram Rinci 7.0

HRD memberikan surat peringatan kepada karyawan melalui sistem dengan mengisikan keterangan pemberian surat peringatan tersebut. Alasan pemberian surat peringatan telah disetujui terlebih dahulu oleh pimpinan sehingga pegawai hanya bisa melihat surat peringatan tersebut.

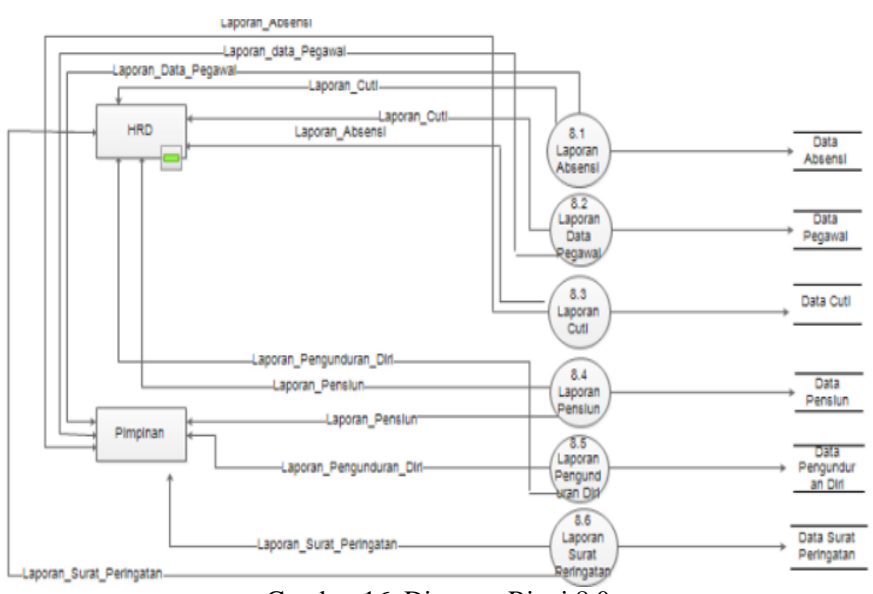

Gambar 16. Diagram Rinci 8.0

Gambar 16 menjelaskan proses yang terjadi pada entitas pimpinan. Pimpinan hanya mendapatkan laporan-laporan yang 
sebelumnya dikelola oleh hrd. Laporan meliputi laporan absensi, laporan data pegawai, laporan cuti, laporan pension, laporan pengunduran diri dan laporan dari surat peringata.

\section{F. Entity Relationship Diagram (ERD)}

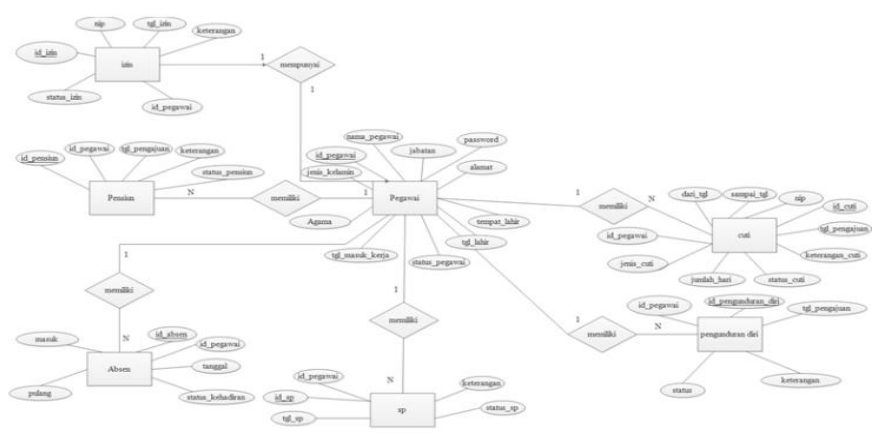

Gambar 17. Entity Relationship Diagram

Pada perancangan yang dibangun dapat dilihat pada gambar 17 mengenai relasi antar entitas. Dimana setiap entitas mempunyai atribut dan primary key. Kardinalitas yang terjadi pada ERD one to many. Satu pegawai bisa banyak mengajukan cuti, izin, pengunduran diri (kondisi jika di tolah saat pengajuan), pengajuan akan di tolak baik itu dari hrd atau pimpinan. Pengajuan juga bisa di tolah jika dilakukan di hari yang sama sehingga pegawai bisa melakukan pengajuan berkali-kali.

\section{HASIL}

\section{A. Rancangan Layar Login}

Rancangan layar pada form login menunjukan tampilan pada saat sebelum masuk ke menu utama aplikasi. Pengguna yang akan masuk dan menggunakan aplikasi diharuskan melakukan proses login terlebih dahulu. Gambar 1 menggambarkan tampilan login yang ada pada PT. Pelayaran Sakti Inti Makmur. Login pengguna didapatkan secara otomatis dengan NIP dari pegawai bersangkutan.

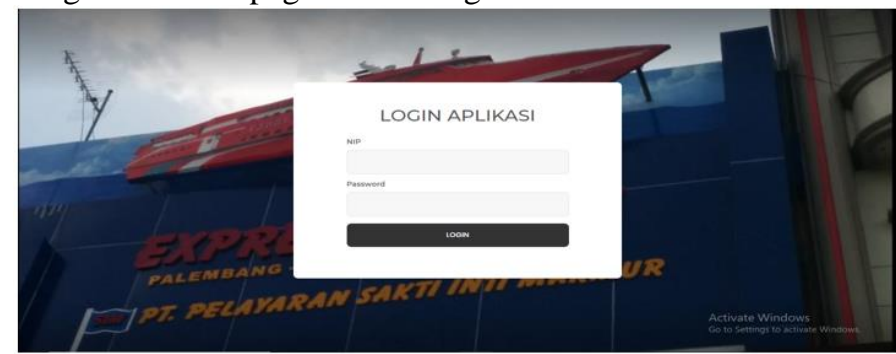

Gambar 18. Rancangan Layar Login

\section{B. Rancangan Layar Beranda}

Gambar 19 memperlihatkan rancangan layar pada form beranda menujukan tampilan pada saat pengguna sudah berhasil login ke dalam aplikasi. Setelah berhasil melakukan login, maka para pegawai bisa melakukan beberapa aktivitas yang dapat dilihat pada menu bagian sebelah kiri (gambar 19).

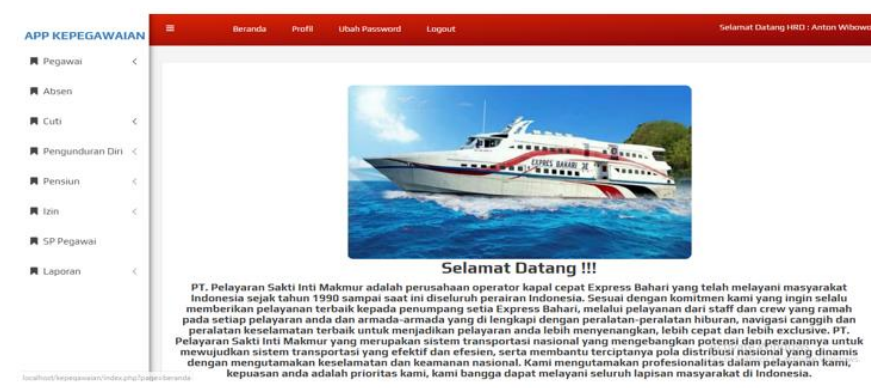

Gämbar 19. Rancangān Layar Beranda

\section{Rancangan Layar Profil}

Gambar 20 menggambarkan form profil dari pegawai, dimana pegawai diminta mengisi profil sebagai kelengkapan informasi. Profil pegawai ini akan bertujuan memudahkan HRD dalam mengkonfirmasi keinginan dari pegawai,

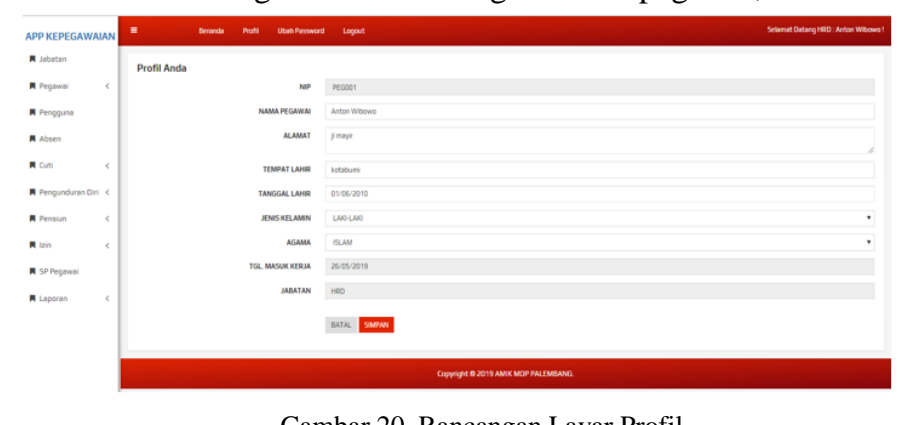

Gambar 20. Rancangan Layar Profil

\section{Rancangan Layar Pegawai}

Gambar 21 memperlihatkan rancangan layar pada form pegawai, menunjukan tampilan ketika HRD ingin menambahkan data pegawai baru pada aplikasi.

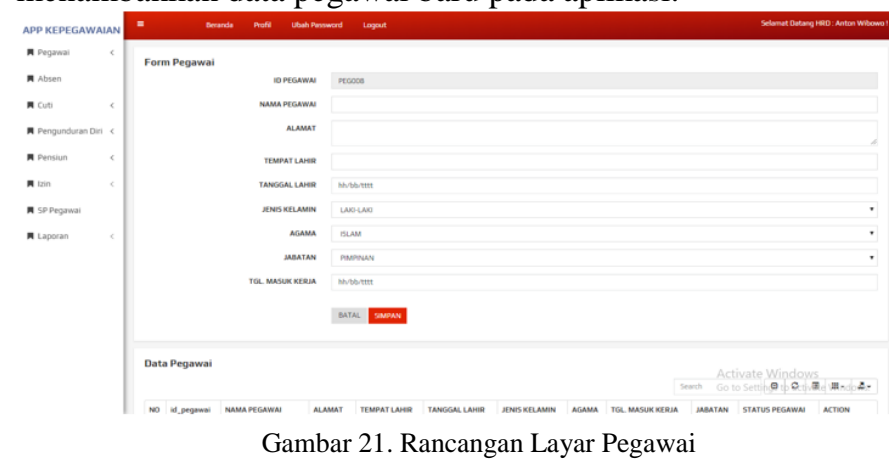

\section{E. Rancangan Layar Masa Kerja}

Gambar 22 menggambarkan rancangan layar pada form masa kerja menunjukan tampilan masa kerja pegawai pada aplikasi. Pada gambar 22, akan terlihat masa kerja dari pegawai bersangkutan baik itu tanggal masuk dari pegawai tersebut maupun masa kerja dari pegawai tersebut. 


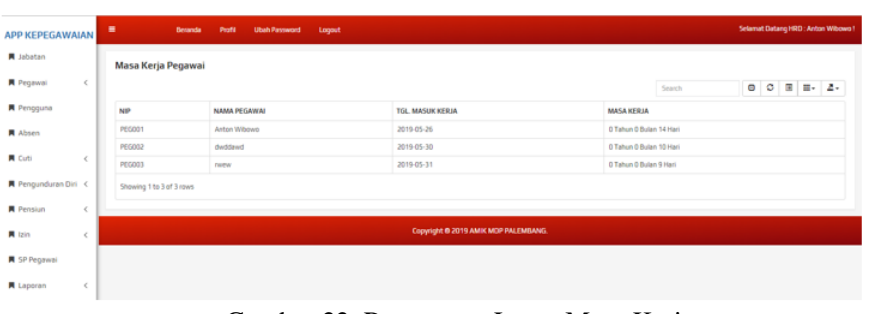

Gambar 22. Rancangan Layar Masa Kerja

\section{F. Rancangan Layar Absen}

Gambar 23 memperlihatkan rancangan layar pada form absen menunjukan tampilan untuk mengisi absen pegawai hari ini baru pada aplikasi. HRD akan melakukan proses absensi kepada pegawai sebagai kehadiran dari pegawai tersebut. Rekap dari absensi bisa dilihat dengan login pegawai masingmasing.

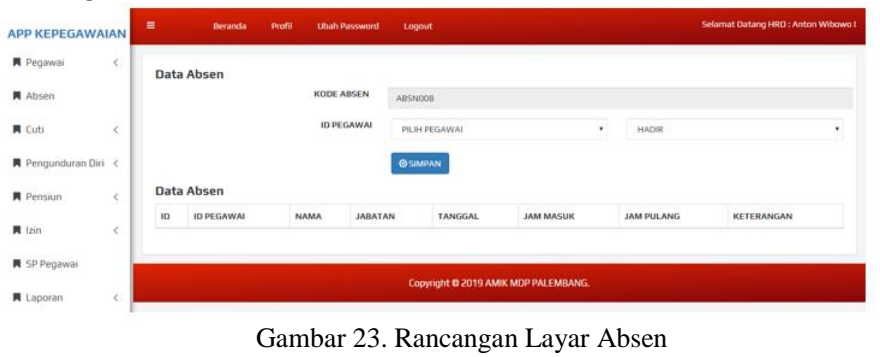

\section{G. Rancangan Layar Pengajuan Cuti}

Gambar 24 menggambarkan rancangan layar pada form pengajuan cuti menunjukan tampilan untuk mengisi cuti pegawai pada aplikasi. Pegawai yang ingin melakukan cuti akan mengisikan keterangan cuti, berapa lama cuti yang diinginkan bahkan memilih jenis cuti. Cuti yang diajukan akan diperiksa kembali oleh HRD dan akan di approve oleh HRD sesuai dengan pertimbangan HRD. Ditolak atau diterima cuti yang diajukan oleh HRD, dapat dilihat oleh pegawai yang bersangkutan dengan melakukan proses login kembali.

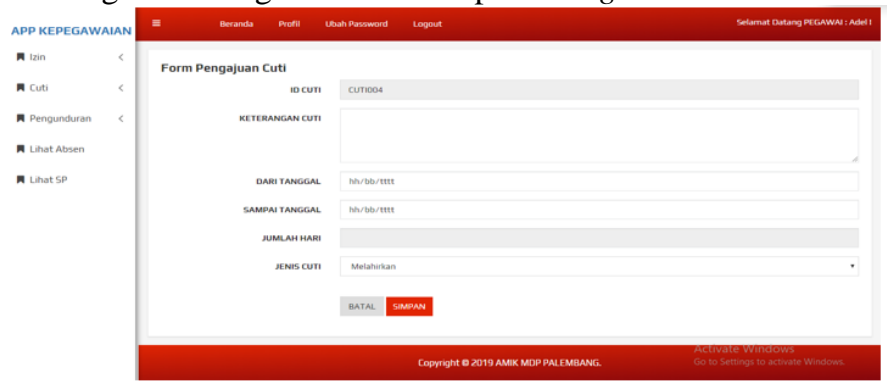

Gambar 24. Rancangan layar Pengajuan Cuti

\section{H. Rancangan Layar Pengunduran Diri}

Gambar 24 menggambarkan rancangan layar pada form pengunduran diri menunjukan tampilan untuk mengisi form pengunduran diri pada aplikasi. Pegawai yang akan melakukan pengunduran diri, akan memberikan alasan pada form tersebut. Pengajuan pengunduran diri akan diteruskan kepada HRD dan
Pimpinan, dan akan dikonfirmasi diterima atau ditolak pengunduran diri tersebut.

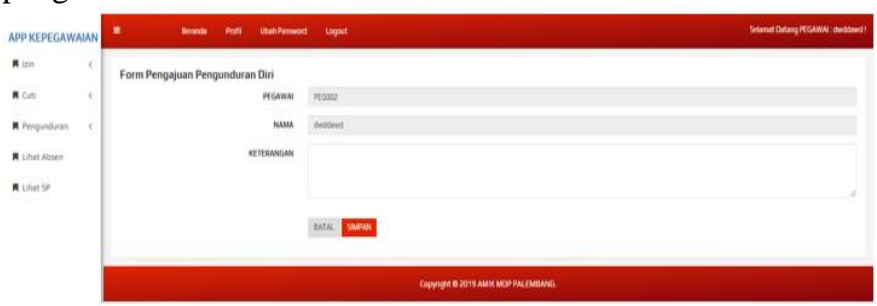

Gambar 25. Rancangan Layar Pengunduran Diri

\section{Rancangan Layar Surat Peringatan}

Gambar 26 memperlihatkan rancangan layar pada formsp menunjukan tampilan untuk memberikan surat peringatan kepada pegawaipada aplikasi. Untuk pemberian surat peringatan akan dimasukkan oleh HRD, pegawai hanya bisa melihat surat peringatan dan alasan dari surat peringatan yang telah dikeluarkan dan disetujui oleh pimpinan.

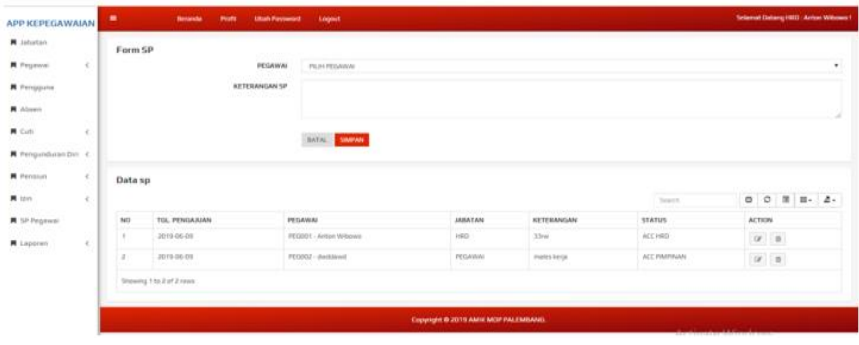

Gambar 26. Rancangan Layar Surat Peringatan

\section{J. Rancangan Layar Permohonan Izin}

Gamabr 27 menggambarkan rancangan layar pada form lihat pengajuan izin menunjukan tampilan untuk melihat apakah izin pegawai disetujui atau tidak pada aplikasi.

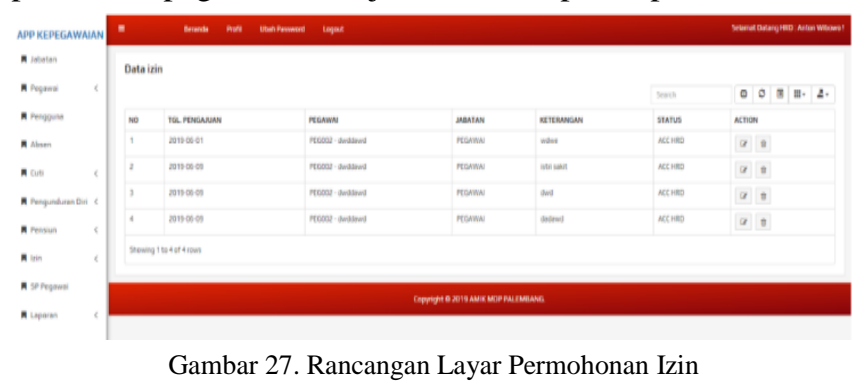

\section{K. Rancangan Layar Pengajuan Pensiun}

Gambar 28 menggambarkan rancangan layar pada form pengajuan izin menunjukan tampilan untuk mengisi izin pegawai pada aplikasi.

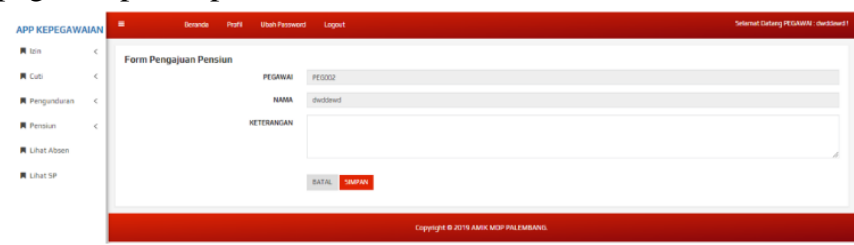

Gambar 28. Rancangan Layar Pengajuan Pensiun 


\section{Pengujian Sistem}

Pengujian sistem yang dilakukan menggunakan metode black box testing dimana hanya menguji unit dan antar muka dari sistem. Hasil yang didapatkan dari pengujian sistem, dapat disimpulkan bahwa sistem berjalan dengan baik. Pengujian antar muka dengan menguji unit sesuai dengan yang diharapkan.

\section{PENUTUP}

Berdasarkan perancangan sistem yang telah dilakukan diharapkan PT. Pelayaran Sakti Inti Makmur dapat mengolah data kepegwaian baik itu mengetahui masa kerja pegawai dalam hal ini pengajuan dan memasuki masa pensiun, proses dalam pengurusan izin, cuti dan pengunduran diri yang lebih mudah serta proses pembuatan laporan dapat lebih cepat dilakukan sehingga kesalahan-kesalahan yang telah terjadi pada proses manual diharapkan tidak terjadi kembali dengan sistem yang telah di bangun.

\section{DAFTAR PUSTAKA}

[1] P. K. Handayani, "SISTEM INFORMASI ADMINISTRASI DATA KEPEGAWAIAN PADA BAGIAN PERSONALIA PT. XYZ," Simteris, vol. 7, no. 1, pp. 373-378, 2016.

[2] M. R. Fachlevi and R. F. Syafariani, "PERANCANGAN SISTEM INFORMASI KEPEGAWAIAN BERBASIS WEBSITE DI BAGIAN
KEPAGAWAIAN SDN BINAKARYA I KABUPATEN GARUT," Simteris, vol. 8, no. 2, pp. 553-558, 2017.

[3] N. Wijaya, "PERANCANGAN APLIKASI PROMOSI SONGKET PALEMBANG BERBASIS ANDROID," JUSIM, vol. 2, no. 2, pp. 1022, 2017.

[4] M. Salahuddin and A. S. Rosa, Modul Pembelajaran Rekayasa Perangkat Lunak (Terstruktur dan Berorientasi Objek). Bandung: Modula, 2011.

[5] S. Supriyadi, "Community of Practitioners: Solusi Alternatif Berbagi Pengetahuan antar Pustakawan," Lentera Pustaka J. Kaji. Ilmu Perpustakaan, Inf. dan Kearsipan, vol. 2, no. 2, pp. 83-93, 2016.

[6] A. Taqwiym and N. WIjaya, "PERANCANGAN LOWONGAN KERJA ONLINE BERBASIS WEB PADA PT ANH," J. Ilm. Inform., vol. 2, no. 1, pp. 112-116, 2017.

[7] B. Raharjo, Pemrograman Web (HTML, PHP, \& MySQL) Edisi Ketiga. Bandung: Modula, 2016.

[8] E. Winarno and A. Zaki, Buku Sakti Pemrograman PHP. Jakarta: Elek Media Komputindo, 2013.

[9] P. Hidayatullah, Visual Basic. Net Membuat Aplikasi Database dan Program Kreatif. Bandung: Informatika, 2012.

[10] F. Al Hanif, Analisis dan Perancagan Sistem Informasi. Yogyakarta: Andi Offset, 2007.

[11] I. Hairil and A. Widjaja, "RANCANGAN SISTEM INFORMASI PENGOLAHAN DATA BANTUAN SOSIAL BERBASIS WEB PADA YAYASAN SAMUDERA NURUSSHOLAH," IDEALIS, vol. 1, no. 3, pp. 16-23, 2018. 